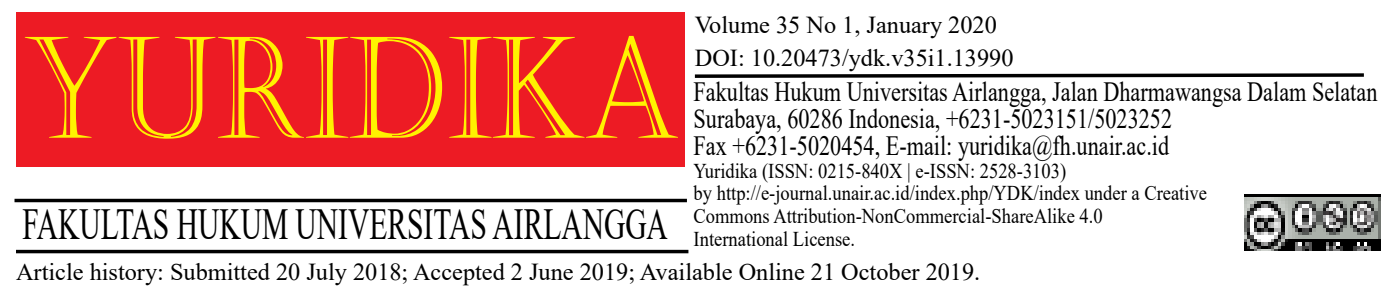

\title{
Protection of Geographical Indications as a Form of Consumer Rights Protection
}

\author{
Dian Ety Mayasari \\ demasari2006@yahoo.co.id \\ Darma Cendika Catholic University
}

\begin{abstract}
The potential of natural resources in a region that is well managed and provides economic benefits to the local communities deserves protection for geographical indications. It is part of intellectual property rights as it relates to the protection of the identities of producer regions that are affected by both human and natural factors. The provision of protection for geographical indications, that adopts a constitutive registration system, put emphasis on the potentials of the certain region because the distinctiveness of a product from the region cannot be found in the others. The protection of geographical indications granted for an unlimited period of time protects not only the producer regions but also the reputation, quality, as well as characteristics of their products. To provide protection of geographical indications means also to protect the consumer rights; consumers that purchase or use certain products are supplied with correct information on the production sites, quality and being protected from the potentially harmful effect of the products.
\end{abstract}

Keywords: Protection; Geographical Indications; Consumer Rights.

\section{Introduction}

Indonesia is known as a maritime country as it consists of so many islands. The latter bring it great potential in the form of natural resources. Natural resource wealth provides benefit to the communities because it may help increase the economic growth provided that they managed it properly. Natural resources management is conducted through the production processes by local people. The quality production processes certainly requires intellectual capacity. The actual outcomes of human intellectual capacity deserve protection. Without any protection of intellectual property, the enthusiasm for producing intellectual work will fade because naturally humans need recognition and appreciation for the 
work they produce. ${ }^{1}$ Products derived from natural and human factors, which are part of the production process intended to produce quality products, deserved geographical indication protection. According to Sommeng and Sasongko, protection of geographical indication lies in a sign that identifies a particular country or a region or a place in that region as the area of origin of a product, where reputation, quality and characteristics of the product are largely determined by the geographical factors in question. ${ }^{2}$ It is expected that geographical indication protection increases the value of products which, in the end, improves the economy of the people in the area of origin of the products.

The protection of geographical indications relating to the origin and the characteristics of the product serves a guarantee for consumers that the product is of good quality. Consumers should not be uninformed about such products as Cilembu sweet potatos that usually available only once a year in a limited quantity, despite the fact that such products flood a number of traditional markets along the street from Tanjungsari to Sumedang, even Yogyakarta, Surabaya, Jakarta, and Bali. ${ }^{3}$ Geographical indication protection should, ideally, provides information and guarantee for consumers that the protection for particular products is provided based on their uniqueness, which means that they are unavailable in other regions and, thereby, bring consumers' satisfaction when they buy or consume such products. Therefore, the problem statement formulated in this paper is how geographical indication protection can realize the protection of consumer rights. The purpose of this paper is to improve the understanding of the relationship between protection of geographical indications and protection of consumer rights.

\footnotetext{
1 Indirani Wauran and Wicaksono, 'Hak Kekayaan Intelektual Sebagai Benda: Penelusuran Dasar Perlindungan HKI Di Indonesia’ (2015) 9 Refleksi Hukum.[137].

2 Yeti Sumiyati, 'Perbuatan Curang Dalam Penggunaan Produk Indikasi Geografis' (2010) 12 Sosiohumaniora.[166].

3 ibid.
} 


\section{Ownership and Registration of Protection of Geographical Indications as Part of Intellectual Property Rights}

Intellectual property rights can be understood as a right that is had by an individual to use its own intellectual works, the rights an individual has for the results of his intellectual work, including enjoying the material and/or non-material benefits of his or her work. ${ }^{4}$ Intellectual property rights encompass two main aspects: ${ }^{5}$ (a) process and product included in a wide variety of fields, from the arts and literature to technological inventions and innovations as well as other forms which are the result of the process of human creativity through his or her creativeness, sense, and intuition; and (b) an inventor owns all rights to his or her invention.

Intellectual property rights refer to the assignment of property rights to an individual or a group of individuals to exercise a monopoly on their work(s). Therefore, the intellectual property right is exclusive and absolute, which means that it can be maintained on behalf of anyone and those who own this right can file a lawsuit for any infringement against it. ${ }^{6}$ The purpose of intellectual property laws is to encourage or motivate people's creativeness to produce innovative and tradable works to gain economic benefits.

Intellectual property rights can be said as economic rights assigned by-laws to a creator or inventor for a work of human intellectual ability. ${ }^{7}$ This means that intellectual property right serves as an award for the innovative work of individuals or a group of individuals that brings benefit to social life. By benefit, we mean particularly economic benefit obtained from either the use of the work or from licensing of intellectual property. The word rights in the 'intellectual property rights' indicate that rights are categorized as intangible objects that persists in tangible objects as stipulated in Article 499 of the Indonesian Civil Code. Material right, according to Subekti, is a right that gives direct power over an object that can be

4 Indirani Wauran and Wicaksono (n 1).[134].

5 Kholis Roisah, Konsep Hukum Hak Kekayaan Intelektual (HKI) Sejarah, Pengertian Dan Filosofi Pengakuan HKI Dari Masa Ke Masa (Setara Press 2015).[7].

6 ibid.[9].

7 Khoirul Hidayah, Hukum Hak Kekayaan Intelektual (Setara Press 2017).[1]. 
defended by every person. ${ }^{8}$ Material rights relating to intellectual property rights constitute property rights as regulated in Article 570, Indonesian Civil Code. It, therefore, can be interpreted that by this property right at his or her disposal, the owner can maintain it or control it in full. As Khoirul Hidayah noted, article 570 of Indonesian Civil Code describes that the ownership rights of an item include the right to control it freely and the right to enjoy it fully, as long as it complies with the law. ${ }^{9}$ Article 574 of the Indonesian Civil Code stipulates that if someone else controls an item without the knowledge of the actual owner, he or she can be demanded to return the item.

Intellectual property rights are divided into two categories: copyright and industrial property rights. Industrial property rights include brands, patents, industrial designs, integrated circuit layout designs, trade secrets, and plant varieties. Geographical indications are part of the brand. This underlines the notion of the geographical indication as a sign that becomes the identity of a product which distinguishes it from others. The geographical indications serve wider function than the brand because the latter is only limited to the issue of producer identity; the brand cannot protect the originality of the origin of the goods. ${ }^{10}$

Previous regulations on geographical indications are specified in Law Number 15 of 2001 concerning Trademarks, which were then specifically described in Government Regulation Number 51 of 2007 concerning Geographical Indications. Currently, there is a change in the regulation with the enactment of Law Number 20 of 2016 on Trademarks and Geographical Indications. The legislation of a country is a system that does not want or justify or allow any conflict within it. ${ }^{11}$ Thus, in this case, the lex superior derogat legi inferiori principle is applicable if there is a conflict in the regulation of substantially similar matters-in this case, the regulation of geographical indications-then the superior norms suppress the inferior ones. Therefore, the legal

\footnotetext{
Subekti, Pokok-Pokok Hukum Perdata (Intermasa 1994).[62].

9 Khoirul Hidayah (n 7).[4].

${ }^{10}$ Trias Palupi Kurnianingrum, 'Perlindungan Hak Ekonomi Atas Indikasi Geografis' (2016)

11 Sudikno Mertokusumo, Mengenal Hukum Suatu Pengantar (Liberty 2003).[92].
} 7 Negara Hukum.[29]. 
discussion regarding the geographical indications will employ the provisions in Law Number 20 of 2016 concerning Trademarks and Geographical Indications.

The term geographical in 'geographical indications', from the aspect of intellectual property rights, refers to a trademark. However, from the definition of geographical indication, it indicates the origin of an item. From the definition of geographical indication in Article 1 number 6 of Law Number 20 of 2016 concerning Trademarks and Geographical Indications we see that geographical indication is a sign that shows the area of origin of an item and/or product that-because of geographical environmental factors, including natural and human factors or any combination thereof-give reputation, quality, and certain characteristics to the produced goods and/or products. It is expected that geographical indication protection will add value to local products as the latter are legally better protected and provide more economic benefits. Therefore, the protection of geographical indications is intended not only to the creativity of the community but also the geographical factors in the area of origin of the product. It is consistent with Djulaeka's opinion that geographical indication protection concern not only the intellectual work by an individual, but mostly because of the influence of geographical, environmental factors that give special characteristics to goods originating in a certain region. ${ }^{12}$

Geographical indications contain four basic elements: ${ }^{13}(1)$ determination of the place of origin of a product; (2) production method specifications; (3) product quality specifications; and (4) name and reputation that distinguish one product from other related products. From the four basic elements, we see that geographical indication protection focuses more on the protection of the place of origin of a product, and, therefore, it put more emphasis on the characteristics and quality. Protection of this area is related to the place or location where the goods are produced.

\footnotetext{
12 Djulaeka, Konsep Perlindungan Hak Kekayaan Intelektual Perspektif Kajian Filosofis HaKI Kolektif-Komunal (Setara Press).[67].

13 I Gusti Ayu Purnamawati, 'Perlindungan Hukum Indikasi Geografis Terhadap Kerajinan Tradisional Untuk Penguatan Ekonomi Wilayah' (2016) 11 Pandecta.[39].
} 
Intellectual property right as a form of state appreciation is not directly granted upon the completion of work, but it must register with the state, and it is known as the constitutive system. Constitutive system guarantees more legal certainty for rightholders compared to a declarative system. This holds because, in case of property right dispute, the determination of who is the right holder is based on who registers his work first with authentic evidence in the form of the registration document. Such a registration process, therefore, offers stronger guarantee of ownership. Likewise, geographical indication protection requires registration and certification processes. Because the geographical indication protection is influenced by natural and human factors, the ownership is communal, rather than individual, in nature.

This complies with Article 53 Paragraph (3) of Law No 20 of 2016 regarding Trademark and Geographical Indications stipulating that those who can apply for geographical indication protection are institutions that represent communities in certain geographical regions that manage items and/or products in the form of natural resources, handicrafts, or industrial products, as well as the provincial or regency/municipal government. The rationale underlying this regulation is that geographical indication protection intends to generate additional economic value to the products not only because of natural factors but also of people's creativeness in producing items that attract consumers' interest.

This communal ownership of geographical indication is very beneficial in terms of maintaining the product quality consistency, despite being lack of competitiveness among the owners as they live in the same region and, consequently, the prices are similar. For consumers, this is very beneficial because they will continue to buy for product distinctiveness that cannot be found in other regions.

Application for geographical indications registration could be dismissed, as stipulated in Article 56 paragraph (1) of Law Number 20 of 2016 concerning Trademarks and Geographical Indications, in case it (a) runs contrary to state ideology, legislation, morality, religion, decency, and public order; (b) misleads or deceives the public regarding reputation, quality, characteristics, source of origin, process of making goods, and/or their uses; and (c) is a name that has been used 
for a plant variety and is used for similar plant varieties, unless there are additional equivalents of words denoting similar geographical indication factors. The registration requires documents describing geographical indications that include information concerning reputation, quality, and characteristics of goods and/or products related to the geographical factors of the goods and/or products submitted for their geographical indications registration.

Application document that contain unverifiable geographical indications could be dismissed on the basis of Article 56 paragraph (2) letter a, of Law Number 20 of 2016 concerning Trademarks and Geographical Indications. The document describing the geographical indications will undergo substantive checks by an Expert Team for Geographical Indications as regulated in Article 59 paragraph (2) of Law Number 20 of 2016 concerning Trademarks and Geographical Indications. The expert team is composed of 15 persons from: (a) ministerial representative; (b) representatives of ministries in charge of agriculture, industry, trade, and/or other relevant ministries; (c) representatives of agencies or institutions authorized to supervise and/or test the quality of goods; and (d) other competent experts. These substantive conditions must not conflict with religious morality, decency, and public order. Also, they must not deceive and mislead the public regarding the nature, characteristics, quality, and area of origin, as well as the process of making or use of products. ${ }^{14}$

Article 61 paragraph (1) of Law Number 20 of 2016 concerning Trademarks and Geographical Indications stipulates that the period of protection for this geographical indication has no limits, provided that the reputation, quality and characteristics protected by this geographical indication are consistently maintained. So, as long as the areas in which the product originates can maintain its specificity, the protection of the geographical indication will remain applicable; on the contrary, if they failed to meet the predetermined requirement, the geographical indication protection will be revoked.

${ }^{14}$ Hendra Djaja, 'Perlindungan Indikasi Geografis Pada Produk Lokal Dalam Sistem Perdagangan Internasional’ (2013) 16 Cakrawala Hukum.[139]. 


\section{Relationship between Geographical Indication Protection and Consumer Right Protection}

Geographical indications and consumers protections are strongly related because the products granted with geographical indication protection are expected to attract consumers' interest and to bring consumer satisfaction after using or consuming them. The benefits of geographical indication protection for consumers are: ${ }^{15}$ (1) quality assurance based on law in compliance with consumer expectations of the product; and (2) legal guarantees for consumers that the products meet the expected standards. Therefore, the protection of geographical indications must pay attention to consumer rights.

The consumer protection is set out in Law Number 8 of 1999 concerning Consumer Protection, where consumer is defined, under Article 1 point 2, as every person who uses goods and/or services available in the community, either for personal and family uses or for relatives or other living beings, and not for resale. From this definition, we can see that consumers are not only those categorized as end-users of product, but there are also intermediate consumers who buy goods or products for resale. While the opposite of consumer is producer, the Law No 8 of 1999 concerning Consumer Protection does not include the word 'producer'. Instead, it uses 'business actor' that, under Article 1 point 3, is defined as every individual or business entity, either legal or non-legal entity, established and domiciled or conducting activities within the jurisdiction of the Republic of Indonesia, either individually or jointly through agreements to conduct business activities in various economic fields. Business actors are not only limited to producers who produce goods and/or services, but also distributors, corporations, and cooperatives; even a trader can also be categorized as a business actor. ${ }^{16}$ The term 'business actor' can be interpreted as having a broader notion than 'producer' which can be identified with manufacturing and production processes, because the former is also related to the process and the field of business that can either be a legal or non-legal entity.

\footnotetext{
${ }^{15}$ I Gusti Ayu Purnamawati (n 13).[35].

16 Eli Wuria Dewi, Hukum Perlindungan Konsumen (Graha Ilmu 2015).[58].
} 
Four basic consumer rights are as follows: ${ }^{17}$ (1) the right to safety; (2) the right to be informed; (3) the right to choose; and (4) the right to be heard. The consumer rights are stipulated in Article 4 of Law No 8 of 1999 regarding Consumer Protection as follows:

a. the right to comfort, security and safety in using goods and/or services;

b. the right of choosing goods and/or services and obtaining the said goods and/ or services in accordance with the exchange value and condition and guarantee pledged;

c. the right to correct, clear and honest information about the condition and guarantee of the goods and/or services;

d. the right that their opinions and complaints about goods and/or services used should be listened to;

e. the right of obtaining advocacy, protection and an endeavor to properly settle disputes over consumers' protection;

f. the right of obtaining consumers' fostering and education;

g. the right of being correctly, honestly and indiscriminatory treated and served;

h. the right of obtaining compensation and or refund if the goods and/or services received do not conform to the agreement or are not as they should be;

i. the rights regulated in other laws.

The objects of geographical indication protection are typically natural products, agricultural products, industrial products, and handicrafts. ${ }^{18}$ Protection of geographical indications means to ensure the product quality, to grant rights to comfort and safety in consuming the products and/or services. Thus, consumers who consume them feel comfortable and safe and kept away from danger when using them. Protection of geographical indications is also intended to grant consumers the right to choosing goods when they visit the certain region and purchase specific products for personal consumption or to buy them as gifts. For these reasons, consumers can get products that worth the money.

Items or products qualified for geographical indication protection are attached with a sign or a label on them. The label shows the country or region name in which the product originates. This is done to convey information to consumers who intend

\footnotetext{
${ }^{17}$ Celina Tri Siwi Kristiyanti, Hukum Perlindungan Konsumen (Sinar Grafika 2014).[30-31].

${ }_{18}$ Tavinayati, [et., al.]., 'Perlindungan Terhadap Hak Kekayaan Intelektual Indikasi Geografis Hasil Pertanian Lahan Basah Sebagai Produk Khas Propinsi Kalimantan Selatan' (2016) 1 Badamai Law Journal.[81].
} 
to buy the products and to grant a right to them, the right to correct, clear and honest information about the condition and guarantee of the goods and/or services. This relates to the right of consumers to get guidance and education regarding a product. A more comprehensive form of information that does not merely emphasize the element of commercialization is part of consumer education. ${ }^{19}$ What business actors need to do, with the increasing number of products from competitors, is to provide more information about their products to consumers to fulfill the right to get guidance and education regarding the product they offered.

Consumers who are dissatisfied with the quality of geographical indication protected products can express their opinions and complaints. Business actors with geographical indication protected products must protect consumers and help with legal protection efforts to grant consumer right. This consumer dispute resolution effort is divided into two: litigation through the judicial process and nonlitigation or non-judicial process. Dispute resolution due to consumer dissatisfaction can lead to claims for compensation or product replacement when the product does not comply with consumer expectation.

Consumers interest in buying products that are protected by geographical indications is inseparable from the value of money they spent, so an equal bargaining position is needed between business actors and consumers. Business actors may not reduce the quality of the product to obtain greater profits because consumers have the right, as stated in letter $\mathrm{g}$, to be treated or served fairly and honestly, and not discriminatory. Business actors may not make one product with several qualities that lead to the classification of consumers, where high-income consumers can buy good quality products and, conversely, low-income consumers can only buy products of low quality, thus resulting in consumer discrimination.

Local peoples, who produce goods protected by geographical indications, if they fulfill the right of consumer, will benefits economically for the reasons that this: ${ }^{20}(1)$ prevents the transfer of ownership rights to use product distinctiveness from

\footnotetext{
${ }^{19}$ Celina Tri Siwi Kristiyanti (n 17).[41].

${ }^{20}$ I Gusti Ayu Purnamawati (n 13).[34].
} 
the local community to other parties; (2) maximizes the added value of products for the local community; (3) provides protection from product counterfeiting; (4) helps improve the marketing of locally distinctive products; (5) increases employment opportunities; (6) supports the development of agrotourism; (7) ensures business continuity; (8) strengthens local economy; (9) accelerates regional development; and (10) improves community welfare. The importance of this geographical indication protection is inseparable from the protection of consumer rights and, therefore, business actors are expected to maintain the quality of their products. The inclusion of natural and human factors in the protection of geographical indications must go hand in hand in an effort to maintan the quality and increase the consumer purchasing decision.

\section{Conclusion}

Geographical indications are part of intellectual property rights aimed at protecting product identities that are influenced by natural and human factors. The protection of geographical indications is synonymous with the protection of areas in which a product originates, and is carried out by a constitutive system. This means that protection will be given after the submission of registration and ownership of geographical indication protection is given communally, rather than individually, in order to promote economic growth for people in certain regions.

Geographical indication protection is not only a matter of acknowledging the potential of natural resources that exist in a region, but also about consumers as targets for business actors whose products obtain protection for geographical indications. This is because products with geographical indication protection are sold under the geographical indication label that shows information regarding the region in which the products originate. The label made by the business actor with geographical indication protected products actually shows not only the location of the product, but also the product content and guarantee of consumer satisfaction when consuming it, so that consumers feel safe and keep out of hazardous content of the products. 
The period of protection for geographical indication has no limits, provided that the reputation, quality and characteristics of the products are consistently maintained. Therefore, as the geographical indication protection is related to consumer right protection, good relationship must be developed between the geographical indication business actors and their consumers. By doing so, business actors can ask for input from consumers to improve product quality because the latter also have the right to be heard, and this could be part of the evaluation to improve product quality.

\section{Bibliography}

Celina Tri Siwi Kristiyanti, Hukum Perlindungan Konsumen (Sinar Grafika 2014).

Djulaeka, Konsep Perlindungan Hak Kekayaan Intelektual Perspektif Kajian Filosofis HaKI Kolektif-Komunal (Setara Press).

Eli Wuria Dewi, Hukum Perlindungan Konsumen (Graha Ilmu 2015).

Hendra Djaja, 'Perlindungan Indikasi Geografis Pada Produk Lokal Dalam Sistem Perdagangan Internasional' (2013) 16 Cakrawala Hukum.

I Gusti Ayu Purnamawati, 'Perlindungan Hukum Indikasi Geografis Terhadap Kerajinan Tradisional Untuk Penguatan Ekonomi Wilayah' (2016) 11 Pandecta.

Indirani Wauran and Wicaksono, 'Hak Kekayaan Intelektual Sebagai Benda: Penelusuran Dasar Perlindungan HKI Di Indonesia' (2015) 9 Refleksi Hukum.

Khoirul Hidayah, Hukum Hak Kekayaan Intelektual (Setara Press 2017).

Kholis Roisah, Konsep Hukum Hak Kekayaan Intelektual (HKI) Sejarah, Pengertian Dan Filosofi Pengakuan HKI Dari Masa Ke Masa (Setara Press 2015).

Subekti, Pokok-Pokok Hukum Perdata (Intermasa 1994).

Sudikno Mertokusumo, Mengenal Hukum Suatu Pengantar (Liberty 2003).

Tavinayati [et.,al.], 'Perlindungan Terhadap Hak Kekayaan Intelektual Indikasi Geografis Hasil Pertanian Lahan Basah Sebagai Produk Khas Propinsi Kalimantan Selatan' (2016) 1 Badamai Law Journal. 
Trias Palupi Kurnianingrum, 'Perlindungan Hak Ekonomi Atas Indikasi Geografis' (2016) 7 Negara Hukum.

Yeti Sumiyati, 'Perbuatan Curang Dalam Penggunaan Produk Indikasi Geografis' (2010) 12 Sosiohumaniora.

HOW TO CITE: Dian Ety Mayasari ‘Protection of Geographical Indications as a Form of Consumer Rights Protection' (2020) 35 Yuridika. 
--This page is intentionally left blank-- 